\title{
Osteoarthrosis in a rural South African Negro population
}

\author{
L. SOLOMON, P. BEIGHTON, AND J. S. LAWRENCE \\ From the Epidemiological Research Unit, Department of Orthopaedic Surgery, University of the Witwatersrand, \\ Johannesburg, South Africa, and Abt. für Rheumatologie und Balneologie im Niedersachsen-Staatsbad Nenndorf, \\ West Germany
}

\begin{abstract}
Solomon, L., Beighton, P., and Lawrence, J. S. (1976). Annals of the Rheumatic Diseases, 35, 274-278. Osteoarthrosis in a rural South African Negro population. The prevalence and distribution of osteoarthrosis has been studied in a South African Negro population. One or more joints were affected in $60 \%$ of the males and $48 \%$ of the females, compared with a prevalence of $55 \%$ in males and $63 \%$ in females in a comparable English population. Multiple osteoarthrosis was significantly less common in the African than in the English population, the difference here being greatest in females. Clinical Heberden's nodes were also very infrequent in the African population. However, the Tswana males had significantly more osteoarthrosis of the metacarpophalangeal and proximal interphalangeal joints than was encountered in English males. This is attributed to the traumatic effect of hard manual work which is carried on into old age among most African populations.
\end{abstract}

Osteoarthrosis is known to be influenced by genetic and occupational factors. Climate, although it affects the symptomatology, does not appear to influence the prevalence of the disease. Attention was first drawn to racial differences in prevalence by Stecher (1948). In a review of 7000 patients in hospital and private practice in the United States he noted a lower prevalence of Heberden's nodes in Negroes than in White Americans; the difference was most marked in females. In Negro populations in Nigeria and Liberia, Muller (1970) found that only $1.6 \%$ of adults have Heberden's nodes compared with $6 \%$ in an age- and sex-matched population in England. Similarly, in a population of Negroes in Jamaica there were fewer Heberden's nodes than in a corresponding population in the North of England (Bremner, Lawrence, and Miall, 1968). This, however, applied only to the idiopathic variety and traumatic nodes were just as common as in Caucasians.

The prevalence and distribution of osteoarthrosis (OA) in a rural South African Negro population are reported here.

\section{Method}

The present study was carried out in the rural Tswana population of Phokeng, an African village situated $\mathbf{8 0}$ miles north-west of Johannesburg. Demographic data? details of sampling, and survey methods have been described elsewhere (Beighton, Solomon, and Valkenburg, 1975). A random sample of the population over 35 years of age was examined. Radiographs of the hands and feet were taken in every case, and of the hips and spine in subjects over 54 years. The assessment and grading of osteoarthrosis were based on the criteria of Kellgren and Lawrence (1957). Joints of one type, such as the distal interphalangeal, or the metacarpophalangeal, were considered as a group; radiographic changes of osteoarthrosis were graded $0-4$, the assessment for each site being determined by the worst joint in the group. Significances were assessed by the $\chi^{2}$ test.

\section{Results}

Radiological evidence of OA (grade 2-4) was observed in $60 \%$ of males and $53 \%$ of females over 35 years old. Direct comparison with the English surveys has not been attempted because the same number of joints was not examined. Among the Tswanas only one or two joints were affected in the vast majority, but $10 \%$ of the males had involvement of three or more joint groups, and five or more joint groups were affected in $1 \%$.

In contrast to the English populations, the Tswana females had little more multiple OA than the males; 


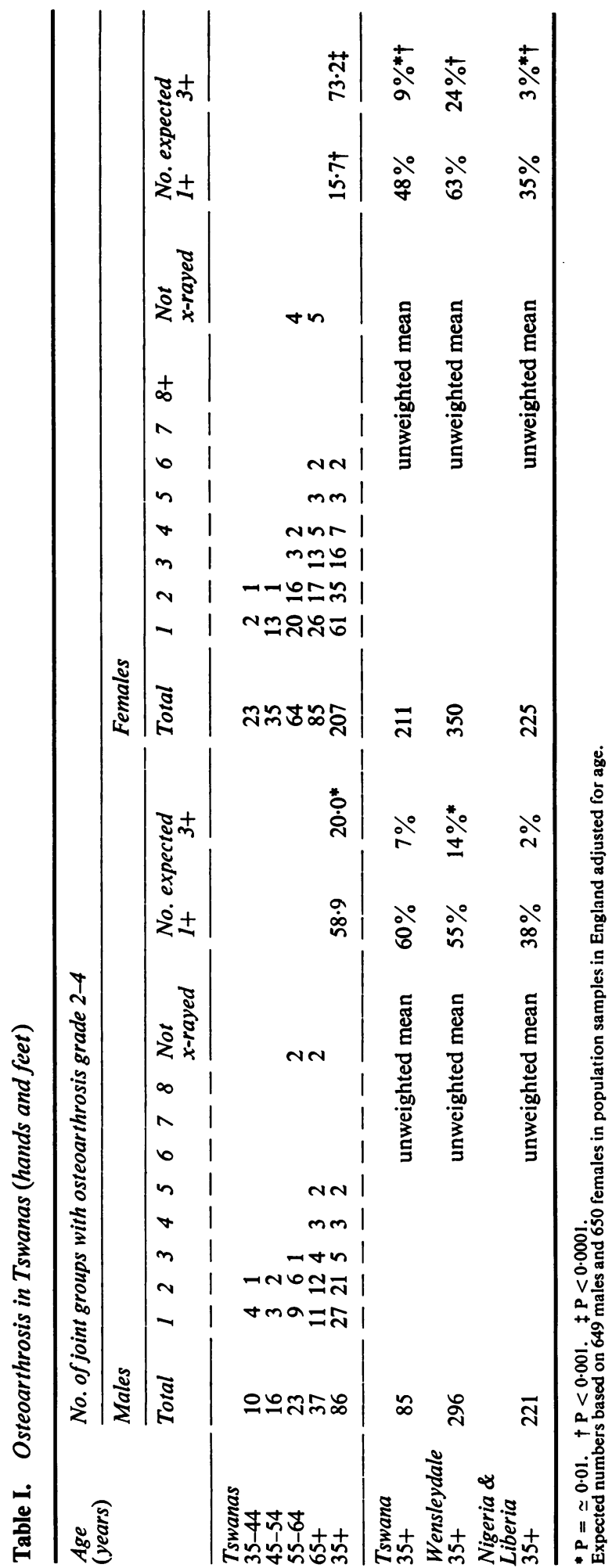


only $12 \%$ had OA in three or more joint groups and $3 \%$ in five or more joints.

Since in some age groups only the hands and feet were $x$-rayed, and in the sample as a whole the joints $x$-rayed were not identical in the Tswana and English populations, the prevalence of $\mathrm{OA}$ in the hands and feet is shown in Table I. The differences between the two groups of women are even more striking than previously suggested: only 5 of the 3 Tswana women over 35 years had OA in five or moreo joint groups, compared with 24 expected in a matched? English population ( $P=\mathbf{0 . 0 0 0 0 1}$ by Fisher's exact test). OA in 5+ joints was thus of much lower frequency but followed a similar gradient.

Table II Osteoarthrosis joint pattern in Tswanas

\begin{tabular}{|c|c|c|c|c|c|c|c|c|c|c|c|c|c|c|c|c|c|}
\hline \multirow{3}{*}{$\begin{array}{l}\text { Age } \\
\text { (years) }\end{array}$} & \multicolumn{8}{|l|}{ Males } & \multicolumn{9}{|c|}{ Females } \\
\hline & \multicolumn{8}{|c|}{ Osteoarthrosis grade } & \multicolumn{8}{|c|}{ Osteoarthrosis grade } & $\vec{\omega}$ \\
\hline & Total & 0 & 1 & 2 & 3 & 4 & $N S$ & $\begin{array}{l}\text { Ex- } \\
\text { pected } \\
2-4\end{array}$ & Total & 0 & 1 & 2 & 3 & 4 & $N S$ & $\begin{array}{l}\text { Ex- } \\
\text { pected } \\
2-4\end{array}$ & $\begin{array}{l}\frac{0}{2} \\
\stackrel{\omega}{\omega}\end{array}$ \\
\hline $\begin{array}{l}\text { DIPs } \\
35-44 \\
45-54 \\
55-64 \\
65+ \\
35+\end{array}$ & $\begin{array}{l}10 \\
16 \\
23 \\
37 \\
86\end{array}$ & $\begin{array}{l}10 \\
13 \\
14 \\
16\end{array}$ & $\begin{array}{l}0 \\
2 \\
1 \\
3\end{array}$ & $\begin{array}{r}1 \\
7 \\
14 \\
22\end{array}$ & $\begin{array}{l}1 \\
5 \\
6\end{array}$ & $\begin{array}{l}1 \\
1\end{array}$ & $\begin{array}{l}2 \\
2\end{array}$ & $\begin{array}{r}0 \cdot 4 \\
0 \cdot 4 \\
7 \cdot 2 \\
20 \cdot 0 \\
28 \cdot 0\end{array}$ & $\begin{array}{r}23 \\
35 \\
69 \\
87 \\
214\end{array}$ & $\begin{array}{l}22 \\
32 \\
36 \\
30\end{array}$ & $\begin{array}{l}0 \\
1 \\
2 \\
5\end{array}$ & $\begin{array}{r}1 \\
2 \\
27 \\
35 \\
65\end{array}$ & $\begin{array}{r}4 \\
16 \\
20\end{array}$ & $\begin{array}{l}1 \\
1\end{array}$ & $\begin{array}{l}3 \\
7\end{array}$ & $\begin{array}{c}0 \cdot 8 \\
4 \cdot 9 \\
32 \cdot 4 \\
65 \cdot 2 \\
103 \cdot 3 *\end{array}$ & $\begin{array}{l}\text { N } \\
\text { s } \\
\text { o } \\
\text { a } \\
\text { c }\end{array}$ \\
\hline $\begin{array}{l}P I P s \\
35-44 \\
45-54 \\
55-64 \\
65+ \\
35+\end{array}$ & $\begin{array}{l}10 \\
16 \\
23 \\
37 \\
86\end{array}$ & $\begin{array}{l}10 \\
16 \\
22 \\
25\end{array}$ & $\begin{array}{l}1 \\
1\end{array}$ & $\begin{array}{l}10 \\
10\end{array}$ & $\begin{array}{l}1 \\
1\end{array}$ & & $\begin{array}{l}2 \\
2\end{array}$ & $\begin{array}{l}0 \\
0 \cdot 5 \\
2 \cdot 1 \\
8 \cdot 5 \\
11 \cdot 1\end{array}$ & $\begin{array}{r}23 \\
35 \\
69 \\
87 \\
214\end{array}$ & $\begin{array}{l}23 \\
35 \\
60 \\
53\end{array}$ & $\begin{array}{r}1 \\
11\end{array}$ & $\begin{array}{r}8 \\
22 \\
30\end{array}$ & $\begin{array}{l}1 \\
1\end{array}$ & & $\begin{array}{l}3 \\
7\end{array}$ & $\begin{array}{c}0 \\
1.6 \\
20 \cdot 3 \\
41 \cdot 8 \text { 월 } \\
63 \cdot 7+\frac{1}{1}\end{array}$ & 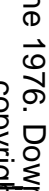 \\
\hline $\begin{array}{l}M C P s \\
35-44 \\
45-54 \\
55-64 \\
65+ \\
35+\end{array}$ & $\begin{array}{l}10 \\
16 \\
23 \\
37 \\
86\end{array}$ & $\begin{array}{r}9 \\
15 \\
18 \\
22\end{array}$ & $\begin{array}{l}0 \\
0 \\
0 \\
1\end{array}$ & $\begin{array}{r}1 \\
0 \\
5 \\
10 \\
16\end{array}$ & $\begin{array}{l}1 \\
4 \\
5\end{array}$ & & $\begin{array}{l}2 \\
2\end{array}$ & $\begin{array}{r}0 \cdot 1 \\
2 \cdot 0 \\
5 \cdot 0 \\
14 \cdot 0 \\
21\end{array}$ & $\begin{array}{r}23 \\
35 \\
69 \\
87 \\
214\end{array}$ & $\begin{array}{l}23 \\
34 \\
62 \\
66\end{array}$ & $\begin{array}{l}0 \\
0 \\
4\end{array}$ & $\begin{array}{r}1 \\
7 \\
14 \\
22\end{array}$ & $\begin{array}{l}3 \\
3\end{array}$ & & $\begin{array}{l}3 \\
7\end{array}$ & $\begin{array}{c}0 \cdot 4 \\
2 \cdot 5 \\
14 \cdot 2 \\
38 \cdot 3 \\
75 \cdot 4_{+}^{+}\end{array}$ & 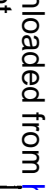 \\
\hline $\begin{array}{l}C M C s \\
35-44 \\
45-54 \\
55-64 \\
65+ \\
35+ \\
\end{array}$ & $\begin{array}{l}10 \\
16 \\
23 \\
37 \\
86\end{array}$ & $\begin{array}{l}10 \\
15 \\
18 \\
33 \\
77\end{array}$ & $\begin{array}{l}0 \\
0 \\
1 \\
1 \\
0\end{array}$ & $\begin{array}{l}0 \\
1 \\
3 \\
3 \\
7\end{array}$ & $\begin{array}{l}0 \\
1 \\
1\end{array}$ & & $\begin{array}{l}2 \\
2\end{array}$ & $\begin{array}{c}0 \\
1 \cdot 0 \\
2 \cdot 9 \\
11 \cdot 5 \\
15 \cdot 4 \mathrm{NS}\end{array}$ & $\begin{array}{r}23 \\
35 \\
69 \\
87 \\
214\end{array}$ & $\begin{array}{r}23 \\
34 \\
67 \\
72 \\
196\end{array}$ & $\begin{array}{l}2 \\
6 \\
8\end{array}$ & $\begin{array}{l}0 \\
1 \\
8 \\
9\end{array}$ & $\begin{array}{l}1 \\
1\end{array}$ & 0 & $\begin{array}{l}1 \\
0 \\
3 \\
7\end{array}$ & $\begin{array}{c}0 \cdot 1 \\
1 \cdot 4 \\
16 \cdot 2 \\
36 \cdot 5 \\
54 \cdot 2 \ddagger\end{array}$ & 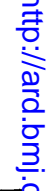 \\
\hline $\begin{array}{l}\text { Wrists } \\
35-44 \\
45-54 \\
55-64 \\
65+ \\
35+\end{array}$ & $\begin{array}{l}10 \\
15 \\
23 \\
33 \\
81\end{array}$ & $\begin{array}{l}10 \\
15 \\
19 \\
27 \\
70\end{array}$ & $\begin{array}{l}0 \\
1 \\
2 \\
3\end{array}$ & $\begin{array}{l}1 \\
3 \\
2 \\
6\end{array}$ & $\begin{array}{l}2 \\
2\end{array}$ & & $\begin{array}{l}2 \\
6\end{array}$ & $\begin{array}{r}0 \cdot 2 \\
1 \cdot 1 \\
3 \cdot 3 \\
6 \cdot 1 \\
10 \cdot 6\end{array}$ & $\begin{array}{r}22 \\
35 \\
67 \\
86 \\
210\end{array}$ & $\begin{array}{r}21 \\
34 \\
62 \\
77 \\
194\end{array}$ & $\begin{array}{l}0 \\
0 \\
4 \\
2 \\
6\end{array}$ & $\begin{array}{l}1 \\
1 \\
1 \\
5 \\
8\end{array}$ & $\begin{array}{l}2 \\
2\end{array}$ & & $\begin{array}{l}1 \\
5 \\
8\end{array}$ & $\begin{array}{l}0 \\
0 \cdot 6 \\
4 \cdot 1 \\
11 \cdot 0 \\
15 \cdot 7\end{array}$ & $\begin{array}{l}\text { 을 } \\
\text { 을 } \\
\text { 궁 } \\
\text { 을. }\end{array}$ \\
\hline $\begin{array}{l}\text { 1st MTPs } \\
35-44 \\
45-54 \\
55-64 \\
65+ \\
35+\end{array}$ & $\begin{array}{l}10 \\
16 \\
23 \\
37 \\
86\end{array}$ & $\begin{array}{r}7 \\
14 \\
20 \\
27\end{array}$ & $\begin{array}{l}0 \\
2 \\
2 \\
2\end{array}$ & $\begin{array}{r}3 \\
1 \\
6 \\
10\end{array}$ & $\begin{array}{l}3 \\
3\end{array}$ & & $\begin{array}{l}2 \\
1\end{array}$ & $\begin{array}{c}3 \\
6 \\
10 \\
19 \\
39 \ddagger\end{array}$ & $\begin{array}{r}23 \\
35 \\
66 \\
88 \\
212\end{array}$ & $\begin{array}{l}20 \\
28 \\
42 \\
56\end{array}$ & $\begin{array}{l}2 \\
5 \\
6 \\
2\end{array}$ & $\begin{array}{r}1 \\
2 \\
17 \\
24 \\
44\end{array}$ & $\begin{array}{l}1 \\
5 \\
6\end{array}$ & $\begin{array}{l}1 \\
1\end{array}$ & $\begin{array}{l}6 \\
6\end{array}$ & $\begin{array}{c}6 \cdot 9 \\
13 \cdot 1 \\
37 \cdot 3 \\
50 \cdot 2 \\
107 \cdot 5 \ddagger\end{array}$ & $\begin{array}{l}0 \\
\text { N } \\
\text { N } \\
\text { O } \\
\text { O } \\
0\end{array}$ \\
\hline $\begin{array}{l}\text { Hips } \\
55-64 \\
65+ \\
55+\end{array}$ & $\begin{array}{l}24 \\
37 \\
61\end{array}$ & $\begin{array}{l}23 \\
35\end{array}$ & $\begin{array}{l}1 \\
0\end{array}$ & $\begin{array}{l}1 \\
1\end{array}$ & $\begin{array}{l}0 \\
0\end{array}$ & $\begin{array}{l}1 \\
1\end{array}$ & $\begin{array}{l}1 \\
2\end{array}$ & $\begin{array}{c}3 \\
7 \\
10^{*}\end{array}$ & $\begin{array}{r}58 \\
80 \\
138\end{array}$ & $\begin{array}{l}57 \\
73\end{array}$ & $\begin{array}{l}0 \\
4\end{array}$ & $\begin{array}{l}1 \\
3 \\
4\end{array}$ & & & $\begin{array}{l}14 \\
14\end{array}$ & $\begin{array}{c}7 \cdot 6 \\
12 \cdot 6 \\
20 \cdot 2 \ddagger\end{array}$ & 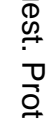 \\
\hline
\end{tabular}


JOINT PATTERN OF OA

The joints most frequently affected in the Tswana, as in most populations, were the distal interphalangeal (DIP) joints of the fingers (Table II). However, while the Tswana males were affected with roughly the same frequency (34\%) as English males, the Tswana women had significantly less involvement of the DIP joints than expected. Indeed, in all joints the Tswana women had much less OA than the English women, while the Tswana men had roughly the expected amount of $\mathrm{OA}$ in the proximal interphalangeal (PIP) and metcarpophalangeal (MCP) joints compared with the English. They had, however, significantly less in the first metatarsophalangeal (MTP) joints $(P<0.0001)$.

\section{HEBERDEN'S NODES}

Distal interphalangeal nodes were present in $5(6 \%)$ Tswana males and $7(3 \%)$ females, compared with an expected number of 21 and 89 respectively in English men and women (Table III). The difference here, especially among the women is highly significant $\left(\chi^{2}=106\right)$. Furthermore, only one of the Tswana men and none of the women with Heberden's nodes had OA in more than 2 joint groups, emphasizing once again the rarity of the 'nodal' form of multiple $\mathrm{OA}$ in Negroes. Non-nodal multiple OA, on the other hand, had the same prevalence in the Tswana as in the English population $(6 \%$ of males and $9 \%$ of females).

OA OF THE HIP

Only 2 men and 4 women over the age of 54 years had any radiological sign of OA of the hip. Among the women in particular the difference from the expected prevalence in a comparable English population was statistically highly significant $(P<0.001)$.

\section{Discussion}

The present study confirms the low prevalence of Heberden's nodes and multiple $\mathrm{OA}$ in African Negroes. Similar findings have been recorded in Negro populations in Nigeria and Liberia (Muller, 1970). Taking a mean of four age groups of 35 years onwards, $60 \%$ of Tswana males had OA of one joint or other, compared with $55 \%$ in Wensleydale and $38 \%$ in Nigeria and Liberia. However, in most of the African males only one or two joints were involved and the condition may well have been traumatic in origin. By contrast, multiple OA (involvement of 3 joint groups or more) was significantly less common in both of the African populations than in the English population. While this applied to both sexes, the difference was particularly marked in the women, of whom only $9 \%$ in the Tswana and $3 \%$ in Nigerian and Liberian had multiple OA, compared with $24 \%$ in Wensleydale $(P<0.001)$. There is, incidentally, also a significant difference between the two groups of Negro women, the Nigerians and Liberians having even less multiple OA than the Tswana $(P<0.01)$.

Another striking feature was the relatively high prevalence of OA of the distal and proximal interphalangeal and metacarpophalangeal joints in the Tswana males as compared with the females, and here again the findings echo similar observations in Negro males in Nigeria and Liberia (Muller, 1970).

One could speculate at length about the possible reasons for the racial differences in the prevalence and pattern of OA. However, no evidence was

Table III Heberden's nodes (HNs) in Tswana and Nigerians

\begin{tabular}{|c|c|c|c|c|c|c|c|c|}
\hline \multirow{3}{*}{$\begin{array}{l}\text { Age } \\
\text { (years) }\end{array}$} & \multicolumn{8}{|c|}{ Grade of Heberden's nodes } \\
\hline & \multicolumn{4}{|l|}{ Male } & \multicolumn{4}{|l|}{ Female } \\
\hline & $\begin{array}{l}\text { Total } \\
\text { examined }\end{array}$ & $\begin{array}{l}\text { HNs } \\
\text { present }\end{array}$ & $N K$ & $\begin{array}{l}\text { Expected } \\
2-4(\text { grade })\end{array}$ & $\begin{array}{l}\text { Total } \\
\text { examined }\end{array}$ & $\begin{array}{l}\text { HNs } \\
\text { present }\end{array}$ & $N K$ & $\begin{array}{l}\text { Expected } \\
\text { grade 2-4 }\end{array}$ \\
\hline $\begin{array}{l}\text { Tswanas } \\
35-44 \\
45-54 \\
55-64 \\
65+ \\
35+\end{array}$ & $\begin{array}{r}9 \\
14 \\
24 \\
38 \\
85\end{array}$ & $\begin{array}{l}0 \\
1 \\
2 \\
2 \\
5\end{array}$ & $\begin{array}{l}1 \\
1 \\
1 \\
1\end{array}$ & $\begin{array}{c}0 \cdot 2 \\
1 \cdot 4 \\
3 \cdot 8 \\
15 \cdot 6 \\
21 \cdot 0 *\end{array}$ & $\begin{array}{r}23 \\
35 \\
71 \\
93 \\
222\end{array}$ & $\begin{array}{l}0 \\
0 \\
4 \\
3 \\
7\end{array}$ & $\begin{array}{l}1 \\
1\end{array}$ & $\begin{array}{l}0 \cdot 6 \\
5 \cdot 2 \\
25 \cdot 4 \\
57 \cdot 7 \\
89 *\end{array}$ \\
\hline \multicolumn{9}{|c|}{ Nigerians and } \\
\hline $\begin{array}{l}35-44 \\
45-54 \\
55-64 \\
65+ \\
35+\end{array}$ & $\begin{array}{r}90 \\
65 \\
57 \\
12 \\
224\end{array}$ & $\begin{array}{l}0 \\
2 \\
3 \\
0 \\
5\end{array}$ & & $\begin{array}{r}2 \cdot 1 \\
6 \cdot 6 \\
9 \cdot 1 \\
4 \cdot 9 \\
23^{*}\end{array}$ & $\begin{array}{r}97 \\
73 \\
54 \\
6 \\
230\end{array}$ & $\begin{array}{l}0 \\
5 \\
3 \\
0 \\
8\end{array}$ & & $\begin{array}{r}2 \cdot 7 \\
11 \cdot 0 \\
19 \cdot 3 \\
3 \cdot 7 \\
37^{*}\end{array}$ \\
\hline
\end{tabular}

* $\mathbf{P}<0.001$.

Expected: Numbers based on 968 males and 1092 females in English population samples in Leigh (Wensleydale) and Watford. NK $=$ not known. 
uncovered in the present study to support any particular theory. It is unlikely that there is an inherent resistance to $O A$ in the South African Negro, for in some joints the disorder was even more common than expected from studies of other races: apart from the high prevalence of metacarpophalangeal OA in the men, clinical evidence of OA of the knee was found in 81 of 212 women examined $(38 \%)$.

The low prevalence of multiple OA might be attributed to the fact that inflammatory polyarthritis is rare in the rural South African Negro (Beighton and others, 1975). It is interesting to recall that the Jamaican population studied by Lawrence and Molyneux (1968) had a high prevalence of inflammatory polyarthritis, and multiple OA was significantly more frequent than in Wensleydale. No relationship, however, has been shown between Heberden's nodes and inflammatory polyarthritis, and it is possible that the racial differences in this form of arthrosis may be genetically determined (Kellgren, Lawrence, and Bier, 1963; Lawrence, 1969).

Differences in occupation may be important too; coal miners, cotton workers, and certain craftsmen have an unusually high prevalence of OA of the joints subjected to occupational stress (Cobb, 1971; Kellgren and Lawrence, 1952; Lawrence, 1961; Tempelaar and Van Breemen, 1932). The South Afri- can Negroes are essentially a labouring people and the men in particular continue to do rough manual work into old age; this could readily account for the high prevalence of metacarpophalangeal and proximal interphalangeal OA in the Tswana males.

The relative paucity of Negro patients with $\mathrm{OA}$ of the hip is well known in South Africa, though this has not been documented before. This observation was supported by the results of the present study; among the women in particular, the difference from the prevalence in Caucasians was highly significant. A similar low prevalence of OA of the hip has been $\overrightarrow{0}$ noted among the Southern Chinese of Hong Kong (Hoaglund, Yan, and Wong, 1973). This has been $\omega$ attributed by some authors to the supposed beneficial effect upon the hip joint of squatting, a habit which is $?$ common among the Chinese and the South African of Negro. A far more likely explanation, however, is the $i$ fact that some of the common disorders that predispose to OA of the hip in women, such as congenital dislocation, subluxation, and acetabular dysplasia, are exceedingly rare in the South African Negro.

The entire question of the relative importance of cultural and genetic factors in the pathogenesis of $\Phi$ osteoarthrosis is being further explored in compara- $\overrightarrow{0}$ tive studies of culturally dissimilar Negro popı lations.

\section{References}

Beighton, P. H., Solomon, L., And Valkenburg, H. (1975) Ann. rheum. Dis., 34, 136 (RA in a rural South African Negro population)

Bremner, J. M., LAWRence, J. S., AND Miall, W. E. (1968) Ibid., 27, 326 (DJD in a Jamaican rural population)

COBв, S. (1971) In, 'The frequency of Rheumatic Diseases'. Harvard University Press, Cambridge, Mass.

Hoaglund, F. T., YAN, A. C. M. C., AND Wong, W. L. (1973) J. Bone Jt Surg., 55A, 545 (Osteo-arthritis of the hip and other joints in Southern Chinese in Hong Kong. Incidence and related factors)

Kellgren, J. H., and LaWrence, J. S. (1952) Brit. J. industr. Med., 9, 197 (Rheumatism in miners)

_- (1957) Ann. rheum Dis., 16, 494 (Radiological assessment of osteo-arthrosis)

- - - AND BIER, F. (1963) Ibid., 22, 237 (Genetic factors in G.O.A.)

LAWRENCE, J. S. (1961) Brit. J. industr. Med., 18, 270 (Rheumatism in cotton operators)

- (1969) Amer. J. Epidemiol., 90, 381 (Generalized osteo-arthrosis in a population sample)

- , AND MolyneuX, M. (1968) Int. J. Biometr., 12, 163 (DJD among populations in Wensleydale, England and Jamaica)

Muller, A. S. (1970) In 'Population Studies on the Prevalence of Rheumatic Diseases in Liberia and Nigeria', p. 105. Plasmans, The Hague

SteCher, R. (1948) Ann. rheum. Dis., 7, 1 (Heberden's nodes)

TempelaAR, H. C. G., AND VAN Breemen, J. (1932) Acta Rheumatologica, 4, 36 (Rheumatism and occupation) 